\title{
Congenital and Intrapartum SARS-CoV-2 Infection in Neonates: Hypotheses, Evidence and Perspectives
}

\author{
Gerardo R. Robaina-Castellanos MD PhD and Solangel de la Caridad Riesgo-Rodríguez MD MS
}

\begin{abstract}
INTRODUCTION Both intrauterine and intrapartum mother-to-child transmission of SARS-CoV-2 have been reported. However, there is still disagreement as to the likelihood and frequency of such vertical transmission.
\end{abstract}

OBJECTIVE Summarize and analyze the published evidence on forms of SARS-CoV-2 vertical transmission (either intrauterine or intrapartum).

EVIDENCE ACQUISITION We carried out a review of literature published in English and Spanish from January 1, 2020 through October 30, 2020. Search engines included PubMed/MEDLINE, SciELO, LILACS, Cochrane, Google Scholar, ResearchGate and medRxiv. There were no restrictions concerning type of study. The review included 48 original research articles, 11 review articles, a meta-analysis, 2 pre-published articles, 15 systematic reviews, and 10 editorials or comments.

DEVELOPMENT Medical thinking on congenital or intrapartum maternal-fetal/neonatal transmission of SARS-CoV-2 has evolved from preliminary evidence that was divided as to whether these forms of vertical transmission were even possible to current evidence support-

\section{INTRODUCTION}

Since the outbreak of the novel coronavirus in late 2019, there have been indications of SARS-CoV-2 infections in neonates.[1] Such infection can be due either to 'vertical' transmission (from mother to child) or to 'horizontal' transmission (from familial contacts or nosocomial infections acquired during hospitalization).

Vertical transmission can occur by one of three mechanisms: intrauterine infection (transplacental or ascending), intrapartum infection (transmission that occurs during birth) and postpartum infection (through breast milk, nasal secretions, etc.) Evidence of transplacental transmission of emerging diseases like HIV, Ebola and Zika suggest the possibility of intrauterine or intra-amniotic transmission of SARS-CoV-2 infection.[3] Positive results from quantitative reverse-transcriptase polymerase chain reaction (RT-PCR) for SARS-CoV-2 RNA during the first few hours or days of life and identification of newborns with manifestations of earlyonset clinical signs and symptoms of COVID-19 would confirm vertical SARS-CoV-2 infection.[1,3]

Given that postnatal transmission from mother to child is also considered 'vertical transmission", the term is imprecise, prompting increasing use of the categories proposed by Shah.[4] Under this

\section{IMPORTANCE}

This article summarizes evidence available on congenital and intrapartum SARS-CoV-2 infection, an understudied aspect of the COVID-19 pandemic that requires more study due to its clinical and healthcare implications. ing both forms of transmission and hypothesizing as to the mechanisms that guide them. The presence of the SARS-CoV-2 virus in maternal, placental, fetal or neonatal tissues has been demonstrated by RT-PCR, specific immunoglobulin detection tests, immunostaining and in-situ hybridization. It is estimated that infections acquired either congenitally or intrapartum occur in $1.8 \%-8.0 \%$ of newborns born to women who test positive for COVID-19 at the end of their pregnancies. This review found 53 neonates who were diagnosed with COVID-19 in the first 48 hours of life by either RT-PCR or specific IgM tests. According to criteria outlined in this review, the timing of infection corresponded to congenital or intrapartum transmission in $39.6 \%$ (21/53) of COVID-19-positive newborns, to postpartum transmission in $15.1 \%$ (8/53) and remains unspecified in $45.3 \%(24 / 53)$.

CONCLUSIONS Congenital and intrapartum SARS-CoV-2 infection in the fetus/newborn is possible, but rare. International collaborative studies using common epidemiological surveillance instruments would allow for a more precise specification of the frequency of congenital and intrapartum SARS-CoV-2 infection at the population level.

KEYWORDS COVID-19; SARS-CoV-2; vertical transmission of infectious disease; infant, newborn

definition, 'vertical transmission' includes congenital infections with intrauterine or perinatal fetal death, congenital infections in living newborns, neonatal infections acquired intrapartum and neonatal infections acquired postpartum (Figure 1).

Determining the possibility of maternal SARS-CoV-2 infection during pregnancy has obvious implications for clinical practice and healthcare. Among others, these include: 1) giving parents a better understanding of the probability of vertical transmission and how it could affect their current or future offspring; 2) allowing for compliance by obstetricians and neonatologists with measures suggested by perinatal care protocols designed to minimize the risk of vertical transmission (e.g. transmission related to the birth route, immediate isolation of suspected or study cases) and guidelines for early maternal skin-to-skin contact, newborn care, optimal time for cord clamping, etc;[5] and 3) allowing for implementation and development of specific protection measures for healthcare workers to help prevent infection during delivery, patient care and neonatal resuscitation. It would also allow the scientific community to evaluate treatments and design drugs aimed at minimizing the risk of transplacental or intrapartum transmission.

Even when both intrauterine and intrapartum mother-to-child transmission of SARS-CoV-2 have been reported, there is still disagreement as to their likelihood and frequency. This article presents a review of current available knowledge on congenital and intrapartum transmission of SARS-CoV-2.

\section{EVIDENCE ACQUISITION}

We reviewed literature published on the topic of SARS-CoV-2 vertical transmission through an exhaustive search of the 
Pubmed/MEDLINE, SciELO, LILACS, Cochrane, Google Scholar, Research Gate and medRxiv databases. There were no restrictions on study type. We used the following search terms: COVID-19, SARS-CoV-2, intrauterine infection, neonatal infection, vertical transmission; as well as their Spanish equivalents. We also searched through the references of review papers that emerged during the search for all other relevant sources. When several reports documented the same case, a single report was selected.

The quality of reports and case series were evaluated using an instrument developed by the Mayo Clinic Center for EvidenceBased Practice.[6] Descriptive observational studies were evaluated using a modified version of the Newcastle-Ottawa scale first introduced by Kotlyar.[7] Evaluation of single studies and document classification was performed independently by each of the authors, who then cross-compared their criteria and resolved their discrepancies as a team. After a thorough selection of the reviewed literature using the above criteria, our review contained 87 publications: 48 original articles, 11 review articles, 1 meta-analysis, 2 pre-publication articles (articles that have not yet undergone peer review), 15 systematic reviews, and 10 editorials or comments.

Only cases documenting congenital infection in live newborns or suspected intrapartum infection were selected, and only if the mother had been diagnosed with COVID-19 during her third trimester of pregnancy and the RT-PCR or serological antibody tests for immunoglobulin $\mathrm{M}(\lg \mathrm{M})$ were positive in the newborn in their first 48 hours of life. In symptomatic neonates, the clinical manifestations should also have occurred within the first 48 hours.

We classified infections according to criteria established by Shah (Figure 1),[4] which specify detection of SARS-CoV-2 in chorionic villi through electron microscopy, through immunohistological techniques using antibodies against viral antigens, and in situ hybridization (detection of RNA targets without affecting cell morphology).[3,8,9]

Patients whose clinical manifestations occurred $\geq 48$ hours after birth were classified as postnatally-acquired neonatal infections. This is in line with Shah's criteria.[4] If it was not possible to specify when the initial infection occurred, the case was classified as 'not yet specified'. We classified maternal infection severity according to guidelines proposed by Wu and McGoogan:[10] mild (without pneumonia or with mild pneumonia); severe (dyspnea, respiratory rate $\geq 30$ respirations per minute, oxygen saturation $\leq 93 \%$, ratio of partial pressure of oxygen to inspired fraction of oxygen $<300$ and/or pulmonary infiltrates $>50 \%$ in $24-48$ hours); or as critical (respiratory failure, septic shock, and/or multiple organ dysfunction or failure.[10]

\section{DEVELOPMENT}

Diagnosis of congenital and intrapartum SARS-CoV-2 infection Evidence of viral replication in fetal lung tissue would provide the most conclusive evidence for intrauterine transmission, but this evidence is inaccessible for obvious technical and ethical reasons. It has therefore been proposed that clinical evidence of vertical transmission be obtained by isolating the virus from samples taken from the placenta, amniotic fluid, umbilical cord and pharyngeal swabs immediately after birth. This last criterion is the one used in clinical practice when testing for intrauterine transmission of SARS-CoV-2.[11]

Among newborns of COVID-19-positive mothers who have also tested positive for SARS-CoV-2, there are asymptomatic cases and cases in which the disease appeared anytime in the first few hours or the first days after birth. Given our current lack of knowledge on infection mechanisms and timing, early-onset disease has been presumed by some authors to be the result of vertical transmission. This practice is under discussion. There is no current consensus defining early-onset neonatal COVID-19; and in fact, time limits vary among studies even for neonatal bacterial infections. [8,12]

The classification scheme proposed by Shah[4] attempts to resolve these inconsistencies based on the direction in which disease transmission occurred by including precise indicators of the most frequently used diagnostic methods for detecting the virus. As there is very little knowledge about SARS-CoV-2 incubation periods in the fetus or neonate, the time periods proposed for each category of infection could change as the incubation process becomes better understood. Symptoms present from birth up to 48 hours after birth indicate congenital or intrapartum infection, but do not confirm whether the infection was transplacental, and the presence of SARS-CoV-2 in placental tissue demonstrated by RT-PCR is not necessarily an indication of transplacental transmission. The efficacy of RT-PCR analysis of nasopharyngeal swab samples in newborns in diagnosing congenital or intrapartum infection has not yet been demonstrated. $[8,13,14]$ The classification scheme by Shah[4] makes reference to specific clinical manifestations of SARS-CoV-2 infection, but the clinical presentation of COVID-19 in newborns is still poorly understood, and both clinical markers and imaging findings remain nonspecific.

We present the current state of medical thinking on maternalfetal/neonatal transmission of SARS-CoV-2, based on studies conducted in newborns of mothers diagnosed with COVID-19 in the third trimester of pregnancy. The information is classified into three groups: evidence that supports non-transmission, evidence of early neonatal infection without demonstrated vertical transmission, and evidence that supports congenital or intrapartum transmission with differing degrees of certainty. The evidence supporting congenital or intrapartum infection was classified according to three out of the five case categories proposed by Shah:[4] confirmed (strong evidence of infection with confirmatory microbiology), probable (strong evidence of infection but lacking confirmatory microbiology) and possible (evidence suggestive of infection but inconclusive).

\section{Group one: no evidence of SARS-CoV-2 vertical transmission} The hypothesis that the SARS-CoV-2 virus is not transmissable to the fetus or newborn via transplacental or intrapartum routes is based on the fact that no cases of vertical transmission were documented during previous coronavirus epidemics (SARSCoV-2 in 2002 and MERS-CoV in 2014) or in either disease since. [15]

In most studies carried out early in the COVID-19 pandemic on whether congenital or intrapartum transmission was possible from infected women, presence of the virus could not be demonstrated 
Figure 1: Fetal/neonatal SARS-CoV-2 infection

\begin{tabular}{|c|c|c|c|}
\hline $\begin{array}{l}\text { Congenital infection with } \\
\text { intrauterine fetal } \\
\text { death/stillbirth }\end{array}$ & $\begin{array}{c}\text { Congenital infection in live born } \\
\text { neonate }\end{array}$ & $\begin{array}{l}\text { Neonatal infection acquired } \\
\text { intrapartum }\end{array}$ & $\begin{array}{l}\text { Neonatal infection acquired } \\
\text { postpartum }\end{array}$ \\
\hline $\begin{array}{l}\text { PCR }(+) \text { or culture }(+) \text { fetal or } \\
\text { placental tissue or examination of } \\
\text { chorionic villi placental cells using } \\
\text { IM, IHC or HIS techniques: } \\
\text { Confirmed } \\
\text { Samples from the fetal surface or } \\
\text { fetal side of the placenta }(+): \\
\text { Possible } \\
\text { Maternal side of the placenta PCR } \\
(+) \text {, but fetal or placental tisssue } \\
\text { culture }(-) \text { or not performed: } \\
\text { Unlikely } \\
\text { Fetal tissue samples obtained via } \\
\text { autopsy PCR }(-) \text { or electron } \\
\text { microscopy }(-) \text { No infection }\end{array}$ & 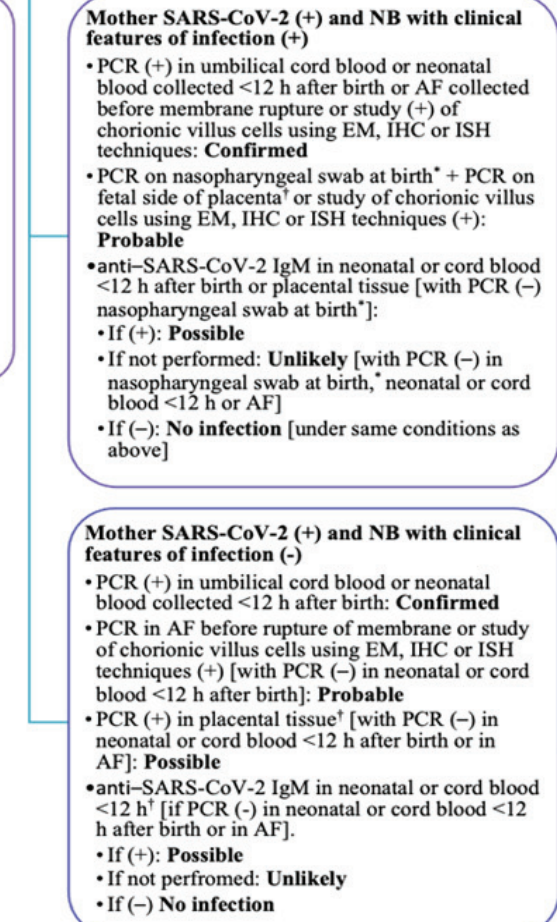 & 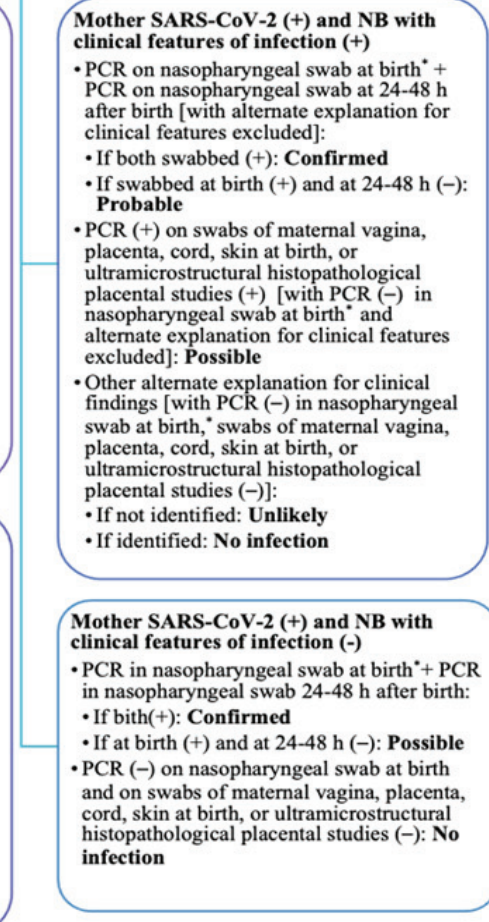 & $\begin{array}{l}\text { NB } \geq 48 \mathrm{~h} \text { of age with clinical } \\
\text { features of infection }(+) \text {, } \\
\text { parents/caregivers may or may } \\
\text { not have } S \text { ARS-CoV-2 } \\
\text { infection or were not tested. } \\
\cdot \text { PCR on nasopharyngeal swab } \\
\text { at birth + PCR on } \\
\text { nasopharyngeal or rectal swabs } \\
\text { at } \geq 48 \text { h after birth } \\
\text { - If }(-) \text { at birth and }(+) \geq 48 \mathrm{~h} \\
\text { after birth: Confirmed } \\
\text { - If at birth (not performed) and } \\
\text { at } \geq 48 \mathrm{~h}(+) \text { : Probable } \\
\text { - If PCR on nasopharyngeal or } \\
\text { rectal swabs at } \geq 48 \mathrm{~h} \text { after } \\
\text { birth }(-) \text { : No infection }\end{array}$ \\
\hline
\end{tabular}

*after cleaning the newborn, †born via cesarean section before rupture of membrane, NB: newborn, AF: amniotic fluid, (+): positive, (-): negative, EM: electron microscopy, IHC: immunohistochemistry, ISH: in-situ hybridization.

Category definitions: Confirmed, Strong evidence of infection with confirmatory microbiology; Probable, Strong evidence of infection but confirmatory microbiology lacking; Possible, Evidence suggestive of infection but incomplete; Unlikely, Little support for diagnosis but infection cannot be ruled out; Not infected, No evidence of infection.

Prepared by Shah[4] (modified by the authors).

in either vaginal secretions, amniotic fluid, tissue samples from the placenta or umbilical cords, or neonatal pharyngeal swabs. $[1,11,16,17]$

Penfield[18] demonstrated exposure to SARS-CoV-2 in three neonates of mothers with severe or critical COVID-19 whose placental or ovular membrane samples were positive for SARSCoV-2. However, none of the neonate samples were positive and none of the newborns showed symptoms of the disease, so the work in question could not demonstrate maternal-fetal transmission.

In this context, it should be noted that little attention has been paid to the proportion of false negatives in RT-PCR tests in children of COVID-19-positive mothers, which, according to studies performed on other age groups, can be up to $100 \%$ when sampling is performed the first day of the incubation period of the disease and $67 \%$ if performed on the fourth day.[19] Thus, it is entirely possible that cases reported as negative at birth or in the first few hours after birth are false negatives.

Group two: early neonatal SARS-CoV-2 infection without demonstrated vertical transmission The possibility of transmission during childbirth was considered when the first cases of newborns with COVID-19-positive mothers tested positive by RT-PCR. Wang[20] reported a newborn who presented with a positive nasopharyngeal sample 36 hours after birth whose COVID-19-positive mother tested negative (by RT-PCR) in samples taken from the pla- centa, umbilical cord and breast milk (Table 1). For similar reasons, it was not possible to prove intrapartum or congenital infection in case series published in China documenting positive pharyngeal samples taken 24-36 hours after birth.[21-23]

Two neonates of mothers with severe or critical COVID-19 tested positive for SARS-CoV-2, one of them in Peru and one in Great Britain, with nasopharyngeal samples obtained, respectively, at 16 hours of life and at birth.[24,25] A newborn tested positive in Italy one day after birth, after receiving breastmilk from their mother, who was unaware that she was positive for COVID-19. [26] The absence of evidence of SARS-CoV-2 in amniotic fluid, umbilical cord blood or placenta makes it impossible to confirm that any of these cases arose from a congenital or intrapartum infection; nor was it possible to determine the timing of infection in four other positive newborns according to RT-PCR in respiratory samples after birth, one reported by Kalane[27] and three others by Savasi.[28]

A prospective population cohort study in Great Britain found 12 SARSCoV-2-positive infants born to mothers with COVID-19, 6 of whom had samples obtained in the first 12 hours of life.[29] This raises the possibility that these infections were acquired either congenitally or during birth, but this cannot be confirmed due to the lack of evidence that would pinpoint the timing of infection. This means these infections must be classified as 'undetermined' as to the timing and route of infection.[29] The same is true for six neonates reported by Sola,[30] all of whom had positive nasopharyngeal samples obtained 
16-36 hours after birth; this study involved 86 pregnant women with COVID-19 confirmed by RT-PCR in seven countries (6 from Latin America, and Equatorial Guinea).

Group three: SARS-CoV-2 congenital or intrapartum transmission confirmed (strong evidence of infection with confirmatory microbiology), probable (strong evidence of infection but confirmatory microbiology lacking) or possible (evidence suggestive of infection but incomplete). The third category summarizes information on SARS-CoV-2-positive newborns for whom we know the timing of infection, who were diagnosed in the first 48 hours of life, and who were born to mothers who contracted COVID-19 in their third trimester (Table 2). Vivanti[31] offered the strongest evidence of transplacental transmission of SARS-CoV-2; namely a preterm newborn who presented with depression at birth followed by neurological signs. RT-PCR tests on the placenta and amniotic fluid were positive for SARS-CoV-2, and immunohistochemical examination of the placenta detected viral nuclear proteins. RT-PCR performed on samples from neonatal lavage, blood, nasopharynx and rectum were also positive. Only cerebrospinal fluid was negative. This case has been classified as a confirmed congenital infection of SARS-CoV-2, with associated neurological manifestations.

There are three other cases of SARS-CoV-2-positive newborns with confirmed congenital infections. The first was a symptomatic full-term newborn whose RT-PCR on respiratory samples was deemed 'doubtful' at birth and positive at 36 and 72 hours of life. Presence of SARS-CoV-2 was also confirmed by electron microscopy, immunohistochemistry, and in situ hybridization. $[32,33]$ The second case was a symptomatic neonate born to a symptomatic mother whose nasopharyngeal samples were negative for SARS-CoV-2 but whose serological studies were positive for the virus. RT-PCR tests taken from the newborn's nasopharynx, from the placenta and from umbilical cord blood were all positive at birth.[34] The third case involved an asymptomatic neonate with negative RT-PCR tests on nasopharyngeal samples on the first and third days of life who nevertheless had positive molecular studies of cord blood and placenta.[35]

Some of the first evidence of congenital SARS-CoV-2 infection was provided by Zamaniyan, who isolated the virus in amniotic fluid using RT-PCR.[36] Nasopharyngeal samples were positive at 24 hours and 1 week of life, but samples from umbilical cord blood, the nasal cavity and the pharynx were negative at birth, making congenital infection likely, given the presence of the virus in the amniotic fluid. Kirstman demonstrated SARS-CoV-2 presence on both the maternal and fetal sides of the placenta in a neonate whose nasopharyngeal samples were positive at birth.[37]

Patanè found RT-PCR evidence of SARS-CoV-2 infection in the mother, the placenta and the newborn.[38] Patanè's study included 22 mother-child dyads, in which only two neonates tested positive for SARS-CoV-2. The first newborn had positive nasopharyngeal samples at birth, at 24 hours and at 7 days after birth; and the second was negative at birth but positive at 7 days of life, despite having no contact with the COVID-19positive mother during this time. Presence of messenger RNA from SARS-CoV-2 spike proteins at the syncytiotrophoblast level was confirmed via in situ hybridization. Both of these cases were classified as probable congenital infections. However, given that nasopharyngeal samples in the second newborn were only positive after seven days of life, this case pushes the boundaries of what we can consider a congenitally-acquired infection and raises the question of whether a positive nasopharyngeal sample obtained after 48 hours accompanied by viral detection on the fetal side of the placenta via in situ hybridization counts according to the classifications used in this review.[4] Both newborns presented with slight feeding difficulties.

Another neonate reported by Sisman[9] was classified as 'probable' for congenitally-acquired COVID-19, while a newborn in a study published by Carosso[39] was classified as 'possible' for infection acquired intrapartum.

Specific tests for IgG and IgM antibodies against SARS-CoV-2 have suggested the possibility of vertical intrauterine transmission in at least three studies.[40-42] In the first two studies,[40,41] three neonates had elevated levels of SARS-CoV-2-specific IgM and IgG. However, negative RT-PCR tests coupled with rapidly declining levels of SARS-CoV-2-specific antibodies in neonatal serum cast doubt on whether these antibodies were produced in the fetuses or neonates or were, instead, relics from the mothers. [43] Unlike IgG antibodies, IgM antibodies do not usually cross the placental barrier. As they can be produced by the fetus, their presence in neonatal serum has been used in diagnosing congenital infections, although the high proportion of false positives and false negatives (likely due to cross-reactivity) has limited their usefulness as diagnostic tests.[8,43,44]

Gao[42] reported on an asymptomatic neonate born to a mother with confirmed symptomatic COVID-19 at 33 weeks gestation. On the day of delivery, both mother and child had negative RT-PCR results from pharyngeal, placental and amniotic fluid samples, but levels were high for IgG and IgM specific to SARS-CoV-2. The possibility of acute maternal and neonatal postpartum infection was ruled out as serial RT-PCR tests performed on the newborn up to 14 days after birth were all negative, with only one positive single-step reverse-transcriptase droplet digital PCR (RT-ddPCR) test-RT-ddPCR is more sensitive than RT-PCR-on the seventh day of life, and the levels of antibodies steadily decreased. Histological studies showed inflammation in the placenta. According to the criteria proposed by Shah,[4] these last four cases of newborns could be classified as congenitally-acquired SARS-CoV-2 infections.

It was difficult to distinguish whether the case reported in Mexico by Hinojasa-Velasco[45] was acquired congenitally or intrapartum, as no samples from the umbilical cord, neonatal blood, placenta or nasopharynx were tested during the time period specified by the criteria outlined in this study.[4] Postpartum infection was ruled out.

Three neonates reported in the series by Martínez-Pérez[46] and two reported by Schwartz[47] were classified as infections possibly acquired intrapartum, as they could not be confirmed as the positive RT-PCR tests on samples from the nasopharynx taken at birth were not repeated 24-48 hours later. McDevitt [48] described a case of possible intrapartum infection garnered from an observational study of neonates included in a universal screening. The neonate in question had positive RT-PCR results at nine hours after birth. The mother was also positive. Both mother and baby were asymptomatic.[48]

The literature we reviewed includes other cases of probable postpartum SARS-CoV-2 infection diagnosed at 48 hours of life 
Table 1: Neonates of COVID-19-positive mothers who tested positive for SARS-CoV-2 in the first 48 hours of life, for whom the timing of infection cannot be pinpointed

\begin{tabular}{|c|c|c|c|c|c|c|c|c|c|c|c|c|}
\hline Reference & $\begin{array}{c}\text { Wang } \\
{[20]}\end{array}$ & $\begin{array}{l}\text { Nie } \\
{[21]}\end{array}$ & $\begin{array}{l}\text { Khan } \\
\text { [22] }\end{array}$ & $\begin{array}{l}\text { Khan } \\
\text { [22] }\end{array}$ & $\begin{array}{c}\text { Zhang } \\
\text { [23] }\end{array}$ & $\begin{array}{c}\text { Alzamora } \\
{[24]}\end{array}$ & $\begin{array}{c}\text { Govind } \\
{[25]}\end{array}$ & $\begin{array}{c}\text { Ferrazzi } \\
\text { [26] }\end{array}$ & $\begin{array}{l}\text { Kalane } \\
\text { [27] }\end{array}$ & $\begin{array}{c}\text { Savasi } \\
\text { [28] }\end{array}$ & $\begin{array}{l}\text { Knight } \\
\text { [29] }\end{array}$ & $\begin{array}{l}\text { Sola } \\
{[30]}\end{array}$ \\
\hline Country & China & China & China & China & China & Peru & $\begin{array}{c}\text { Great } \\
\text { Britain }\end{array}$ & Italy & India & Italy & $\begin{array}{c}\text { Great } \\
\text { Britain }\end{array}$ & $\begin{array}{l}\text { Latin America and } \\
\text { Equatorial Guinea }\end{array}$ \\
\hline Study type & CR & DO & CS & CS & CS & CR & CS & DO & CR & DO & DO & DO \\
\hline Evidence quality & Good & Fair & Fair & Fair & Fair & Fair & Fair & Fair & Good & Poor & Fair & Fair \\
\hline Mothers (No.) & 1 & 1 & $1^{*}$ & $2^{*}$ & 1 & 1 & 1 & 1 & 1 & $3^{* *}$ & $6^{* *}$ & $6^{* *}$ \\
\hline Maternal symptoms & S-M & S-M & S-M & A & S-M & S-SC & S-SC & $\mathrm{S}-\mathrm{U}$ & S-M & S-M & S-NS & S-NS \\
\hline GA (weeks) & 40 & NS & 40 & 39 & 39 & 33 & 39 & NS & 32 & NS & $\begin{array}{r}\text { PT 3, } \\
\text { FT 3 }\end{array}$ & NS \\
\hline Birth type & C & C & $\mathrm{C}$ & C & $\mathrm{C}$ & C & C & C & C & V & $\mathrm{C}$ & NS \\
\hline RT-PCR, NP/OP & $(+)$ & $(+)$ & $(+)$ & $(+)$ & $(+)$ & $(+)$ & $(+)$ & $(+)$ & $(+)$ & $(+)$ & $(+)$ & $(+)$ \\
\hline $\begin{array}{l}\text { RT-PCR, vaginal } \\
\text { secretions }\end{array}$ & NS & NS & NS & NS & NS & NS & NS & NS & NS & NS & No & NS \\
\hline RT-PCR, breast milk & $(-)$ & NS & NS & NS & NS & NS & NS & NS & NS & NS & NS & NS \\
\hline Newborns (No.) & 1 & 1 & $1^{*}$ & $2^{*}$ & 1 & 1 & 1 & 1 & 1 & $3^{* *}$ & $6^{* *}$ & $6^{* *}$ \\
\hline Apgar $1 / 5 / 10$ min & $8 / 9$ & $\begin{array}{r}8-9 / \\
9-10\end{array}$ & $9 / 10$ & $9 / 10$ & NS & $6 / 8$ & $5 / 9$ & $5 \min >7$ & $7 / 7$ & NS & NS & NS \\
\hline Neonate symptoms & S & A & A & A & $\mathrm{S}$ & S & S & NS & S & A & NS & S \\
\hline $\begin{array}{l}\text { RT-PCR, cord/cord } \\
\text { blood }\end{array}$ & $(-)$ & $(-)$ & $(-)$ & $(-)$ & NS & NS & NS & NS & No & NS & No & NS \\
\hline RT-PCR, NP/OP & $(+)$ & $(+)$ & $(+)$ & $(+)$ & $(+)$ & $(+)$ & $(+)$ & $(+)$ & $\begin{array}{r}\text { ET Secr } \\
(+)\end{array}$ & $(+)$ & $(+)$ & $(+)$ \\
\hline $\begin{array}{l}\text { Birth- } 1^{\text {st }} \text { sample } \\
(+)(\mathrm{h})\end{array}$ & 36 & 36 & 24 & 24 & 30 & 16 & At birth & 24 & 24 & 24 & $<12$ & $16-36$ \\
\hline RT-PCR, rectal/stool & $(-)$ & NS & NS & NS & NS & NS & NS & NS & NS & NS & NS & NS \\
\hline $\begin{array}{l}\text { RT-PCR over time } \\
\text { (hours or days) }\end{array}$ & $\begin{array}{r}N P(-) \\
17 \mathrm{~d}\end{array}$ & $\begin{array}{r}\mathrm{OP}(-) \\
4,8 \mathrm{y} \\
15 \mathrm{~d}\end{array}$ & NS & NS & NS & $\mathrm{NP}(+) 2 \mathrm{~d}$ & NS & NS & $\begin{array}{l}\text { ET Secr } \\
(+) 4 d\end{array}$ & NS & NS & NS \\
\hline RT-PCR, AF & $(-)$ & & No & No & NS & NS & NS & NS & No & NS & NS & NS \\
\hline $\begin{array}{l}\text { RT-PCR, placenta, } \\
\text { membranes }\end{array}$ & $(-)$ & $(-)$ & No & No & NS & NS & NS & NS & No & NS & No & NS \\
\hline $\begin{array}{l}\text { Evidence of SARS- } \\
\text { CoV-2 in placenta } \\
\text { (specific technique) }\end{array}$ & NS & NS & NS & NS & NS & NS & NS & NS & NS & NS & NS & NS \\
\hline $\begin{array}{l}\text { SARS-CoV-2 lgG/ } \\
\text { lgM at birth }\end{array}$ & NS & NS & NS & NS & No & $(-) /(-)$ & NS & NS & NS & NS & NS & NS \\
\hline Classification & NS & NS & NS & NS & NS & NS & NS & NS & NS & NS & NS & NS \\
\hline
\end{tabular}

CR: case report CS: case series DO: descriptive/observational S-SC: symptoms-severe or critical S-M: symptoms-mild S-NS: symptoms-severity not specified GA: gestational age PT: preterm FT: full-term C: cesarean V: vaginal (+): positive (-): negative NS: not specified RT-PCR: real-time polymerase chain reaction S: symptomatic A: asymptomatic NP: nasopharyngeal OP: oropharyngeal ET Secr: endotracheal secretion IgG: immunoglobulin G IgM: immunoglobulin M IP: intrapartum PP: postpartum ${ }^{*}$ Different mothers or newborns reported from a same study ${ }^{* *}$ Number of mothers or newborns.

by nasopharyngeal RT-PCR or by bronchoalveolar aspirate in children of pregnant women positive for COVID-19 (Table 2). [4954] During the course of this review, we did not find any casecontrol or cohort studies that reported the presence of congenital and intrapartum infections as the most likely case.

Population studies, systematic reviews and meta-analyses Low incidence of neonatal infection has been found in population studies of COVID-19-positive mothers (confirmed by RT-PCR tests). A prospective cohort study by Khoury in the United States found a $2.5 \%$ (6/236) incidence rate of early-onset neonatal infection in newborns of COVID-19-positive mothers screened with nasopharyngeal swabs at 24 hours of life, repeated serially up to 96 hours of life.[55] The aforementioned study by Knight in the UK reported that of a total of 265 neonates screened for the virus, approximately 5\% (12/265) were positive, half of whom tested positive during the first 12 hours of life.[29]
Universal screening for COVID-19 in neonates born to asymptomatic mothers has shown unexpected results: of 418 newborns screened, $9(2.2 \%)$ were positive for SARS-CoV-2 in the first 12 hours of life; $3(0.7 \%)$ of whom tested positive within the first 3 hours after birth. Eight of nine mothers had negative RT-PCR tests. The only one RT-PCR positive newborn whose mother was COVID-19-positive in this case series is shown in Table 2.[48]

Table 3 summarizes results of systematic reviews focusing on congenital and intrapartum SARS-CoV-2 infections in newborns. [56-68] In the review published by Gajbhiye,[61] the frequency of neonates born to COVID-19-positive mothers testing positive for SARS-CoV-2 via either RT-PCR or antibody tests was $7.6 \%$ (24/313); while Lopes-Sousa found a lower prevalence, with $1.8 \%$ (9/493).[64] A secondary analysis undertaken by Gajbhiye[61] that only took into account neonates diagnosed within the first 48 hours 
Review Article

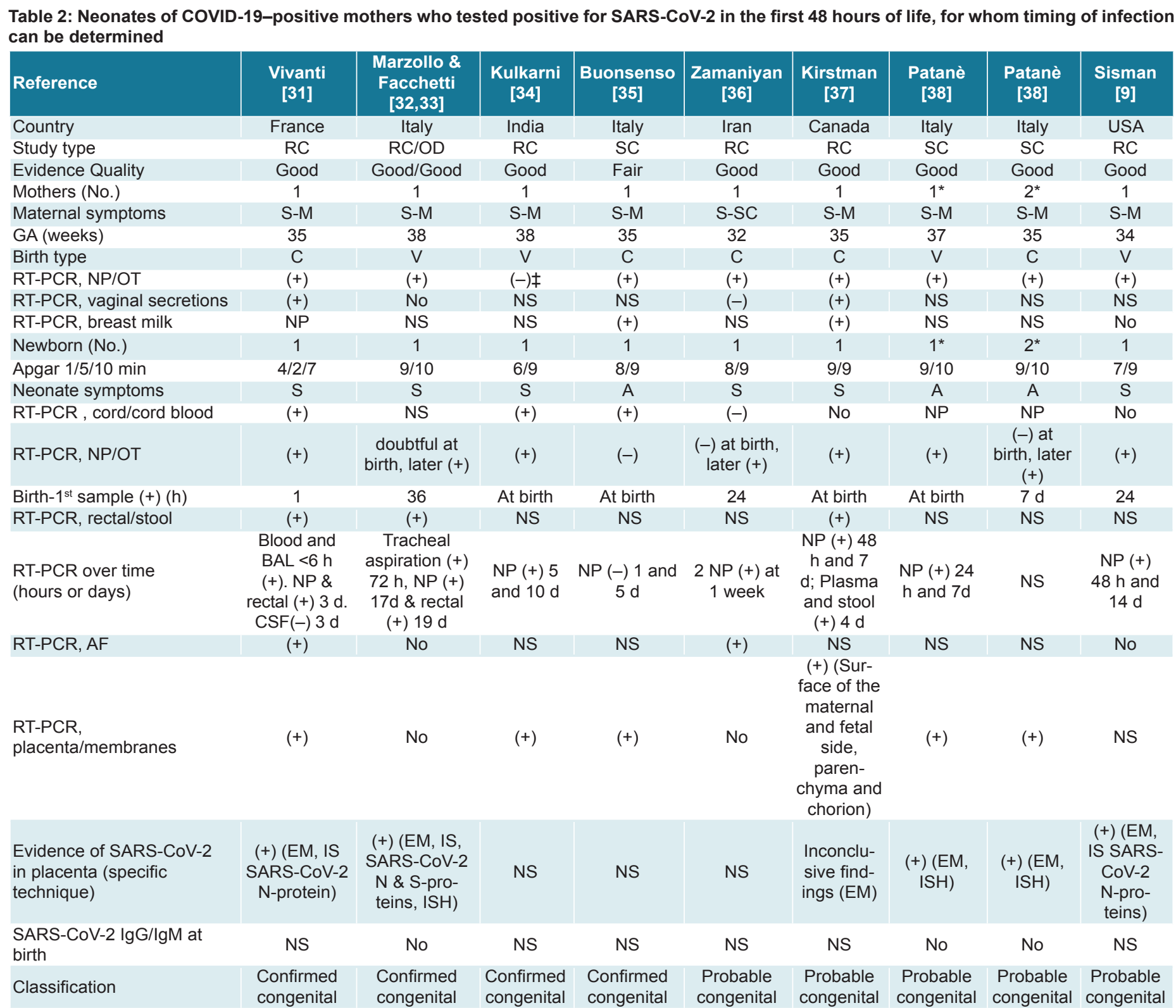

CR: case report CS: case series DO: descriptive/observational S-SC: symptoms-severe or critical S-M: symptoms-mild S-NS: symptoms- severity not specified GA: gestational age PT: preterm FT: full-term C: cesarean V: vaginal (+): positive (-): negative NS: not specified RT-PCR: real-time polymerase chain reaction S: symptomatic A: asymptomatic NP: nasopharyngeal OP: oropharyngeal Secr ET: endotracheal secretion IgG: immunoglobulin G IgM: immunoglobulin M NA: not apply IP: intrapartum PP: postpartum BAL: broncoalveolar lavage CSF: cerebrospinal fluid ABA: broncoalveolar aspirate RT-ddPCR: reverse transcription droplet digital polymerase chain reaction EM: electron microscopy ISH: in-situ hybridization IS: immunostaining IgG: immunoglobulin G IgM: immunoglobulin M *Different mothers or newborns reported from a same study **Number of mothers or newborns łserological studies positive for SARS-CoV-2

found a frequency of $8.0 \%$, which constitutes an estimate of the frequency of infections acquired either congenitally or intrapartum.

A systematic review by Dhir[66] also using criteria developed by Shah[4] includes 58 newborns diagnosed positive for COVID-19 by RT-PCR, regardless of whether or not the mother was positive. Frequency of infections acquired congenitally, intrapartum or postpartum was $6.9 \%$ (4/58), $0.0 \%(0 / 58)$ and $70.7 \%(41 / 58)$, respectively. In $22.4 \%$ (13/58) of newborns, the timing of infection could not be determined.

Another systematic review examing all newborns confirmed positive for SARS-CoV-2 by RT-PCR, which did consider either maternal COVID-19 status or the child's age at diagnosis, found 112 neonates whose infection timing was known, $29.5 \%(36 / 122)$ corresponding to congenital or intrapartum infections, and the remainder to infections acquired postpartum. Of these 36 infants, in $30.6 \%(11 / 36)$ the timing of infections (congenital or intrapartum) was classified as confirmed. In 25/36 (69.4\%) the timing of infections was classified as probable or possible. In addition to the 112 infants assessed in this analysis, the review included another 54 infants for whom it was not possible to specify the timing of infection due to insufficient data in the original articles.[67] Authors of this systematic review used the classification scheme developed by Shah.[4] 


\section{(Continuation of Table 2)}

\begin{tabular}{|c|c|c|c|c|c|c|c|c|c|c|}
\hline Reference & $\begin{array}{c}\text { Carosso } \\
\text { [39] }\end{array}$ & $\begin{array}{l}\text { Dong } \\
{[40]}\end{array}$ & $\begin{array}{c}\text { Zeng H } \\
\text { [41] }\end{array}$ & $\begin{array}{c}\text { Zeng H } \\
\text { [41] }\end{array}$ & $\begin{array}{l}\text { Gao } \\
{[42]}\end{array}$ & $\begin{array}{c}\text { Hinojosa- } \\
\text { Velasco } \\
\text { [45] }\end{array}$ & $\begin{array}{c}\text { Martínez- } \\
\text { Pérez } \\
\text { [46] }\end{array}$ & $\begin{array}{c}\text { Schwartz } \\
{[47]}\end{array}$ & $\begin{array}{c}\text { Schwartz } \\
{[47]}\end{array}$ & $\begin{array}{l}\text { McDevitt } \\
\text { [48] }\end{array}$ \\
\hline Country & Italy & China & China & China & China & Mexico & Spain & Iran & Iran & USA \\
\hline Study type & CR & CR & CS & CS & CR & CR & CS & CS & CS & DO \\
\hline Evidence quality & Fair & Fair & Fair & Fair & Good & Good & Poor & Poor & Poor & Fair \\
\hline Mothers (No.) & 1 & 1 & $1^{*}$ & $2^{*}$ & 1 & 1 & $3^{* *}$ & $1^{*}$ & $2^{*}$ & 1 \\
\hline Maternal symptoms & S-M & S-SC & S-NS & S-NS & S-NS & S-SC & A/S-M & S-SC & S-NS & A \\
\hline GA (weeks) & 37 & 34 & ND & NS & 38 & 38 & $\begin{array}{l}\text { PT 2, GA } \\
\text { NS } 1\end{array}$ & 34 & 34 & 42 \\
\hline Birth type & V & C & C & C & C & C & V 2, C 1 & C & C & C \\
\hline RT-PCR, NP/OP & $(+)$ & $(+)$ & $(+)$ & $(+)$ & $(+)$ & $(+)$ & $(+)$ & $(+)$ & $(+)$ & $(+)$ \\
\hline $\begin{array}{l}\text { RT-PCR, vaginal } \\
\text { secretions }\end{array}$ & $(-)$ & $(-)$ & NS & NS & NS & NS & NS & NS & NS & NS \\
\hline RT-PCR, breast milk & $(-)$ & $(-)$ & NS & NS & NS & $(+)$ & NS & NS & NS & NS \\
\hline Newborn (No.) & 1 & 1 & 1 & 2 & 1 & 1 & $3 \dagger$ & 1 & 2 & 1 \\
\hline Apgar $1 / 5 / 10$ min & $9 / 10$ & $9 / 10$ & $8-9 / 9-10$ & $8-9 / 9-10$ & $8 / 9$ & $8 / 9$ & $\begin{array}{c}5 \text { min }>5 \text { in } \\
2 \text { and }<5 \\
\text { in } 1\end{array}$ & $4 / 5$ & $9 / 10$ & NS \\
\hline Neonatal symptoms & 1 & 1 & $1^{*}$ & $2^{*}$ & 1 & 1 & $3^{\star *}$ & $1^{*}$ & $2^{*}$ & 1 \\
\hline $\begin{array}{l}\text { RT-PCR, cord/cord } \\
\text { blood }\end{array}$ & $(-)$ & NS & $(-)$ & $(-)$ & $(-)$ & No & NS & NS & NS & NS \\
\hline RT-PCR, NP/OP & $(+)$ & $(-)$ & $(-)$ & $(-)$ & $(-)$ & $(+)$ & $(+)$ & $(+)$ & $(+)$ & $(+)$ \\
\hline Birth- $1^{\text {st }}$ sample $(+)(h)$ & At birth & NA & NA & NA & NA & At birth & At birth & 2 & 1 & 9 \\
\hline RT-PCR, rectal/stool & NS & NS & NS & NS & $(-)$ & $(+)$ & NS & NS & NS & NS \\
\hline $\begin{array}{l}\text { RT-PR over time } \\
\text { (hours or days) }\end{array}$ & $N P(-) 37 \mathrm{~h}$ & $\begin{array}{l}5 \text { tests }(-) \\
\text { from } 2 \mathrm{~h} \\
\text { to } 15 \mathrm{~d}\end{array}$ & NS & NS & $\begin{array}{l}\text { NP and } \\
\text { rectal (-) } \\
7 \mathrm{~d} \text {. RT- } \\
\text { ddPCR (+) } \\
7 \mathrm{~d}\end{array}$ & $\begin{array}{c}\text { Stool (+) } \\
4 \mathrm{~d}, \mathrm{NP} \text { y } \\
\text { stool }(-) \\
13 \mathrm{~d}\end{array}$ & $\mathrm{NP}(-) 2 \mathrm{~d}$ & NS & NS & No \\
\hline RT-PCR, AF & No & NS & NS & NS & $(-)$ & NS & NS & NS & NS & NS \\
\hline $\begin{array}{l}\text { RT-PCR, placenta/ } \\
\text { membranes }\end{array}$ & $(-)$ & NS & NS & NS & $(-)$ & No & NS & NS & NS & NS \\
\hline $\begin{array}{l}\text { Evidence of SARS- } \\
\text { CoV-2 in placenta } \\
\text { (specific } \\
\text { technique) }\end{array}$ & NS & NS & NS & NS & NS & NS & NS & NS & NS & NS \\
\hline $\begin{array}{l}\text { SARS-CoV-2 IgG/lgM } \\
\text { at birth }\end{array}$ & $(+/-)$ & $+/+$ & $+/+$ & $+/+$ & $+/+$ & NS & NS & NS & NS & NS \\
\hline
\end{tabular}

Classification

Possible Possible Possible Possible Possible Probable Possible Possible Possible Possible intrapartum congenital congenital congenital congenital intrapartum intrapartum intrapartum intrapartum intrapartum

CR: case report CS: case series DO: descriptive/observational S-SC: symptoms-severe or critical S-M: symptoms-mild S-NS: symptoms- severity not specified GA: gestational age PT: preterm FT: full-term C: cesarean V: vaginal (+): positive (-): negative NS: not specified RT-PCR: real-time polymerase chain reaction S: symptomatic A: asymptomatic NP: nasopharyngeal OP: oropharyngeal Secr ET: endotracheal secretion IgG: immunoglobulin G IgM: immunoglobulin M NA: not apply IP: intrapartum PP: postpartum BAL: broncoalveolar lavage CSF: cerebrospinal fluid ABA: broncoalveolar aspirate RT-ddPCR: reverse transcription droplet digital polymerase chain reaction EM: electron microscopy ISH: in-situ hybridization IS: immunostaining IgG: immunoglobulin G IgM: immunoglobulin $\mathrm{M}$ *Different mothers or newborns reported from a same study ${ }^{* *}$ Number of mothers or newborns łserological studies positive for SARS-CoV-2

An article currently in publication summarizes the largest number of COVID-19-positive mothers and their newborns (1787 motherchild pairs). Only $2.7 \%$ (49/1787) of newborns tested positive.[68] However, diagnostic criteria are not specified. This percentage is similar to that found by Lopes-Sousa,[64] at 1.8\% (9/493) and its authors confirm that this percentage is similar to the frequency of newborns (2/71) affected in the three previous coronavirus epidemics (SARS-1, MERS, HKCoVISARS), in which the only two neonates reported were diagnosed during the HKCoV/SARS epidemic. Both reviews $[64,68]$ assume these to be cases of vertical transmission.

A meta-analysis by Kotlyar[7] includes newborns with diagnoses of COVID-19 in the first 48 hours after birth born to women diagnosed with COVID-19 in their third trimester of pregnancy. The authors found that frequency of vertical infection varies according to diagnostic method: nasopharyngeal $(3.2 \%, 27 / 936)$, placental $(7.7 \%, 2 / 26)$, serological $(3.7 \%, 3 / 82)$ or umbilical cord blood samples $(2.9 \%, 1 / 34)$.

In our review, we identified 53 reports of COVID-19 cases diagnosed in the first 48 hours of life. The rates of infections acquired either congenitally or intrapartum were $24.5 \%(13 / 53)$ and $15.1 \%(8 / 53)$, respectively, in addition to $15.1 \%(8 / 53)$ whose infection timing was classified as postpartum. The timing of infection could not be determined in $45.3 \%(24 / 53)$ This was due to the decision by the authors to classify all cases via strict adherence to the classification criteria established for this study, with the aim of gaining precision in classifying cases, especially those acquired either in-utero or during birth (Figure 2).

Epidemiological analyses have confirmed the possibility of intrauterine or intrapartum SARS-CoV-2 transmission, but the frequency of presentation is low. Even in COVID-19-positive 
(Continuation of Table 2)

\begin{tabular}{|c|c|c|c|c|c|c|c|c|}
\hline Reference & $\begin{array}{c}\text { Zeng L } \\
\text { [49] }\end{array}$ & $\begin{array}{c}\text { Zeng L } \\
\text { [49] }\end{array}$ & $\begin{array}{c}\text { Zeng L } \\
\text { [49] }\end{array}$ & $\begin{array}{c}\text { Bordbar } \\
\text { [50] }\end{array}$ & $\begin{array}{c}\text { Lorenz } \\
\text { [51] }\end{array}$ & $\begin{array}{c}\text { Sinelli } \\
\text { [52] }\end{array}$ & $\begin{array}{c}\text { Pierce- } \\
\text { Williams } \\
\text { [53] }\end{array}$ & $\begin{array}{c}\text { Gregorio- } \\
\text { Hernández } \\
{[54]}\end{array}$ \\
\hline Country & China & China & China & Iran & Germany & Italy & USA & Spain \\
\hline Study type & DO & DO & DO & $\mathrm{CR}$ & $\mathrm{CR}$ & $\mathrm{CR}$ & DO & CS \\
\hline Evidence quality & Fair & Fair & Fair & Good & Good & Good & Fair & Good \\
\hline Mothers (No.) & $1^{*}$ & $2^{*}$ & $3^{*}$ & 1 & 1 & 1 & 1 & 1 \\
\hline Maternal symptoms & S-M & A & A & A & S-L & A & S-SC & S-M \\
\hline GA (weeks) & 40 & 40 & 31 & NS & 40 & FT & NS & 38 \\
\hline Birth type & C & C & $\mathrm{C}$ & $\mathrm{C}$ & V & V & NS & V \\
\hline RT-PCR, NP/OP & $(+)$ & $(+)$ & $(+)$ & $(+)$ & $(+)$ & $(+)$ & $(+)$ & $(+)$ \\
\hline RT-PCR, vaginal secretions & NS & NS & NS & NS & NS & NS & NS & NS \\
\hline RT-PCR, breast milk & NS & NS & NS & NS & NS & NS & NS & NS \\
\hline Newborn (No.) & $1^{*}$ & $2^{*}$ & $3^{*}$ & 1 & 1 & 1 & 1 & 1 \\
\hline Apgar $1 / 5 / 10 \mathrm{~min}$ & NS & NS & $3 / 4 / 5$ & $8 / 9$ & $9 / 9$ & $9 / 10$ & NS & NS \\
\hline Neonatal symptoms & $S$ & $S$ & $\mathrm{~S}$ & $\mathrm{~S}$ & S & $\mathrm{S}$ & A & S \\
\hline RT-PCR, cord/cord blood & NS & NS & NS & No & NS & NS & NS & No \\
\hline RT-PCR, NP/OP & $(+)$ & $(+)$ & $(+)$ & $(+)$ & $(+)$ & $(+)$ & $\begin{array}{l}(-) 24 \mathrm{~h}, \\
\text { after }(+)\end{array}$ & $\mathrm{ABA}(+)$ \\
\hline Birth- $1^{\text {st }}$ sample $(+)(\mathrm{h})$ & 48 & 48 & 48 & 48 & \pm 48 & $48-72$ & 48 & $\geq 48$ \\
\hline RT-PCR, rectal/stool & $(+)$ & $(+)$ & $(+)$ & NS & $(+)$ & NS & NS & NS \\
\hline RT-PR over time (hours or days) & $\begin{array}{l}\mathrm{NP}(+) 4 \mathrm{~d} \\
\text { and }(-) 6 \mathrm{~d}\end{array}$ & $\begin{array}{l}\mathrm{NP}(+) 4 \mathrm{~d} \\
\text { and }(-) 6 \mathrm{~d}\end{array}$ & $\begin{array}{l}\mathrm{NP}(+) 4 \mathrm{~d} \\
\text { and }(-) 7 \mathrm{~d}\end{array}$ & $N P(-)>4 d$ & $\begin{array}{l}\text { NP and rectal } \\
(+) 14 \mathrm{~d}\end{array}$ & $\begin{array}{l}\mathrm{NP}(+) 15 \\
\text { and } 21 \mathrm{~d}\end{array}$ & NS & NS (-) $8 d$ \\
\hline RT-PCR, AF & NS & NS & NS & NS & NS & NS & NS & NS \\
\hline RT-PCR, placenta/membranes & NS & NS & NS & NS & NS & NS & NS & NS \\
\hline $\begin{array}{l}\text { Evidence of SARS-CoV-2 in } \\
\text { placenta (specific technique) }\end{array}$ & NS & NS & NS & NS & NS & NS & NS & NS \\
\hline SARS-CoV-2 lgG/lgM at birth & NS & NS & NS & NS & NS & NS & NS & NS \\
\hline Classification & $\begin{array}{l}\text { Probable } \\
\text { postpartum }\end{array}$ & $\begin{array}{l}\text { Probable } \\
\text { postpartum }\end{array}$ & $\begin{array}{l}\text { Probable } \\
\text { postpartum }\end{array}$ & $\begin{array}{l}\text { Probable } \\
\text { postpartum }\end{array}$ & $\begin{array}{l}\text { Probable } \\
\text { postpartum }\end{array}$ & $\begin{array}{l}\text { Probable } \\
\text { postpartum }\end{array}$ & $\begin{array}{l}\text { Probable } \\
\text { postpartum }\end{array}$ & $\begin{array}{l}\text { Probable } \\
\text { postpartum }\end{array}$ \\
\hline
\end{tabular}

CR: case report CS: case series DO: descriptive/observational S-SC: symptoms-severe or critical S-M: symptoms-mild S-NS: symptoms- severity not specified GA: gestational age PT: preterm FT: full-term C: cesarean V: vaginal (+): positive (-): negative NS: not specified RT-PCR: real-time polymerase chain reaction S: symptomatic A: asymptomatic NP: nasopharyngeal OP: oropharyngeal Secr ET: endotracheal secretion IgG: immunoglobulin G IgM: immunoglobulin M NA: not apply IP: intrapartum PP: postpartum BAL: broncoalveolar lavage CSF: cerebrospinal fluid ABA: broncoalveolar aspirate RT-ddPCR: reverse transcription droplet digital polymerase chain reaction EM: electron microscopy ISH: in-situ hybridization IS: immunostaining IgG: immunoglobulin G IgM: immunoglobulin $M$ *Different mothers or newborns reported from a same study ${ }^{* *}$ Number of mothers or newborns $\ddagger$ serological studies positive for SARS-CoV-2

cases identified during the first 48 hours of life, incidence of vertical transmission represents less than half of all cases, although it should be noted that this figure could be biased as it was not possible to determine the timing of infection in almost half of all cases.

Possible mechanisms driving SARS-CoV-2 vertical transmission The mechanisms by which SARS-CoV-2 can cause

Figure 2: Distribution according to timing of infection. SARS-CoV-2-positive neonates diagnosed during the first $\mathbf{4 8}$ hours of life born to COVID-19-positive mothers, $N=53(n, \%)$

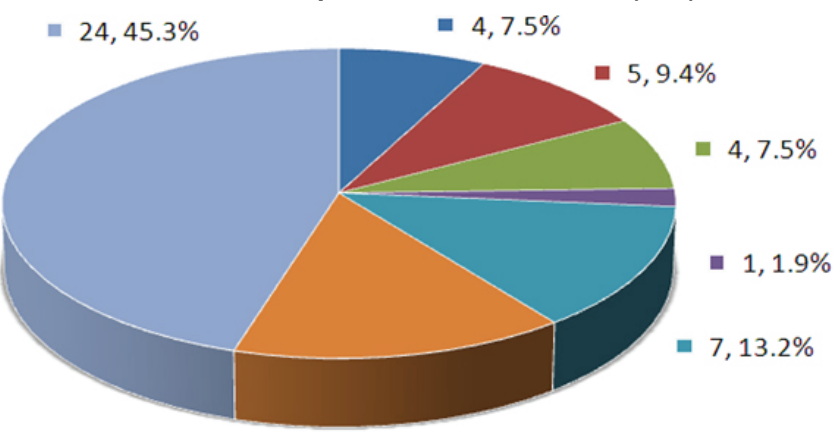

- $8,15.1 \%$

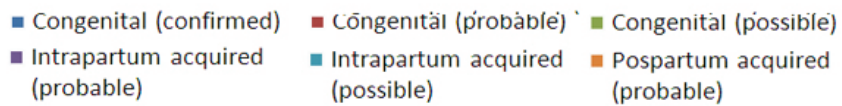

congenital or intrapartum infections are still unknown. In congenital SARS-CoV-2, there are currently four proposed pathways of infection: 1) direct infection of the syncytiotrophoblast and introduction through the syncytial layers via certain receptors, specifically angiotensin-converting enzyme 2 (ACE2) and Fc receptors; 2) exposure to extravillous trophoblasts or other placental cells through maternal circulation; 3) viral passage through cells in the placenta; and 4) ascending infection through the maternal vaginal tract and cervix. In intrapartum infections, one of the main mechanisms of transmission appears to be through maternal vaginal secretions. $[69,70]$ Aspiration of amniotic fluid or maternal blood at birth has also been considered. $[8,14]$

Epidemiological studies have not demonstrated increased risk of miscarriage for COVID-19-positive women.[29] Placental changes consisting of defects in the proliferation and formation of chorionic villi, typical of early stages of pregnancy, occur in a similar proportion to the rate of SARS-CoV-2 infections in the first trimester of pregnancy, which might suggest a correlation between these two rare phenomena. In more advanced stages of pregnancy, placental insufficiency and its direct consequence, intrauterine hypoxia, become more important from both pathophysiological and epidemiological standpoints. Research suggests that placental insufficiency and intrauterine hypoxia occur in $20 \%$ (9/45) of pregnancies involving COVID-19-positive mothers.[68] 
Table 3: Systematic reviews of SARS-CoV-2 vertical transmission in living newborns

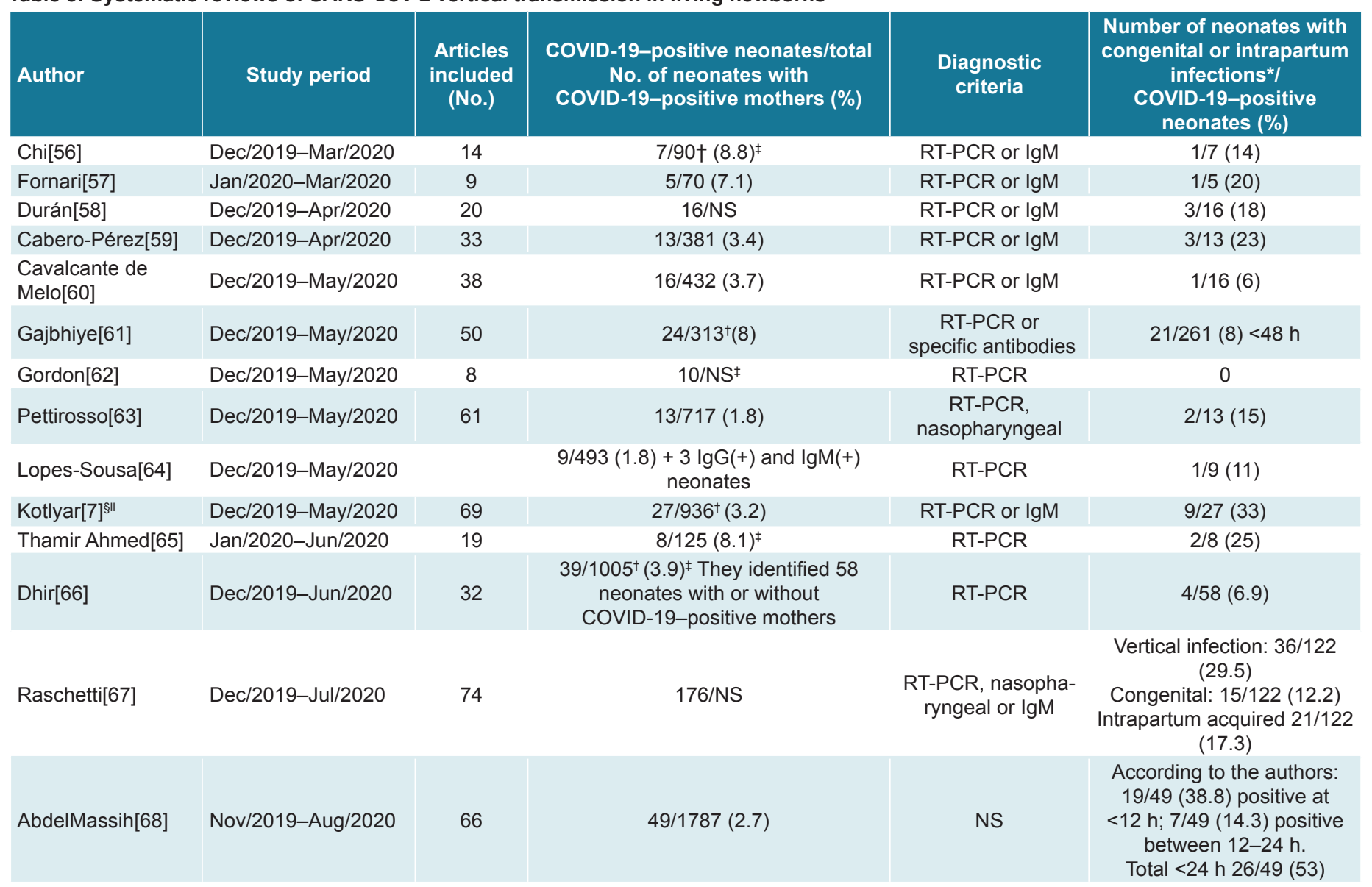

*According to modified criteria by Shah et al.[4] †Number of newborns tested $\ddagger$ Patients who recur in different studies were excluded §lncludes only COVID-19-positive neonates diagnosed at $\leq 48 \mathrm{~h}$ after birth II Includes meta-analysis of vertical transmission NS: not specified IgG: immunoglobulin G IgM: immunoglobulin M

Placental studies of women diagnosed with COVID-19 in their third trimester have shown signs of poor maternal and fetal vascular perfusion in fetuses and newborns negative for SARSCoV-2.[69] Studies of COVID-19-positive neonates have shown chronic intervillitis with macrophage infiltrates at the placental level.[38] This was also the case in the placenta of a dead fetus, also COVID-19-positive.[71] Evidence of placental SARS-CoV-2 by in situ hybridization, immunostaining or visualization of viral particles by transmission electron microscopy in newborns whose nucleic acid tests were negative suggests that even in cases where SARS-CoV-2 is present in the placenta, the risk of vertical transmission is limited.[70,72]

The placenta constitutes an immunological barrier guarding against vertical transmission of pathogens, which could minimize colonization of the syncytiotrophoblast and subsequent transmission of SARSCoV-2 to the fetus. An important immunomodulatory factor is the maternal-fetal interface, which is composed in turn of the decidua derived from the mother and the placenta derived from the fetus.[73]

ACE2 expression is extensive in the female genital tract and in the feto-placental unit. ACE2 expression varies during the stages of pregnancy; via RNA sequencing of individual cells, some authors have found that it tends to increase as gestation progresses, [74] while others report ACE2 messenger RNA expression is higher in placental cells during the early phases of pregnancy.[75]
Analysis of transcriptomes in placental cells has shown low co-expression levels of ACE2 receptors and transmembraneserine protease 2 (TMPRSS2), suggesting that the virus may use other pathways to enter placental cells, which could differ from the pathways currently being suggested.[76]

Facchetti[33] analyzed expression of SARS-CoV-2 spike proteins (S) in 101 placentas using immunohistochemical techniques. Of the 101 placentas, 15 belonged to mothers who tested positive for COVID-19. Of all the placentas studied, only one-belonging to a newborn with pneumonia who had previously been described as positive for SARS-CoV-2-showed high expression of viral S and nucleocapsid (NC) proteins in the syncytiotrophoblast.[32] SARS-CoV-2 RNA was detected in synctiotrophoblast and intervillous inflammatory cells by in situ hybridization, and particles morphologically consistent with the novel coronavirus were visualized by electron microscopy in the cytoplasm of syncytiotrophoblast cells, the endothelium of fetal capillaries, fibroblasts and mononuclear cells. High expression of $\mathbf{S}$ and NC viral proteins were found in areas of dense inflammation, with a predominance of monocytes and macrophages, as well as in maternal and fetal villous cells. These findings suggest that infections can spread via circulating viruses present in infected fetal mononuclear cells, after recruitment of maternal inflammatory cells, without resulting in villitis. The fact that this was found in only 1 of the 101 placentas examined in the study also supports the notion that vertical transmission of SARSCoV-2 via the transplacental route is a rare event. 
The rarity of this phenomenon has also been suggested by results of other research. Hecht studied 19 placentas from mothers with COVID-19 and detected presence of SARSCoV-2 by in situ hybridization in only 2.[13] Examinations using immunohistochemical techniques demonstrated ACE2 expression differs from that of TMPRSS2 in placentas of women who contracted COVID-19 during pregnancy. ACE2 was localized in the synctiotrophoblast, away from maternal blood sources and mainly in the stroma. TMPRSS2 was present only and sparsely in the villous endothelium and rarely in the syncytiotrophoblast. Taglauer[77] visualized the location and relative abundance of the SARS-CoV-2 spike glycoprotein and the colocalization of the ACE2 and TMPRSS2 proteins using comparative immunofluorescence in placental samples from 15 pregnant women with COVID-19, 5 of whom showed evidence of vertical transmission. In cases with and without evidence of vertical transmission, there was evidence of the presence of the SARS-CoV-2 spike glycoprotein in the villous compartment of placental tissues and predominance of ACE2 protein expression over TMPRSS2 protein expression. Both ACE2 and spike gylcoproteins were consistently expressed in the outer layer of the syncytiotrophoblast of placental villi, in juxtaposition with placental regions associated with maternal blood flow.

The fact that viremia has been found in only $1 \%$ of COVID-19 patients[78] also supports the proposition that vertical transmission of SARS-CoV-2 via the transplacental route is a rare event.

The impact of disease severity in the mother on the likelihood of congenital infection is still under discussion. It has been suggested that congenital infection could be more frequent in cases of women with severe or critical infections,[24] and less frequent after a short-term exposure to the virus in the early stages of fetal development. Speculative explanations have been proposed based on viral incubation periods and the limitations of diagnostic tests. [14] However, a recent study reports presence of SARS-CoV-2 in chorionic villi endothelial cells and, to a lesser extent, in trophoblasts, in COVID-19-positive pregnant women with mild manifestations of the disease.[79] Maternal comorbidities such as preeclampsia, diabetes mellitus and other diseases that can influence expression of ACE2 receptors, as well as certain HLA haplotypes and polymorphisms of immunoregulatory genes, should be taken into account.[70]

In our review, in eight of nine confirmed or probable cases of congenital infection, maternal disease was mild, which seems to suggest that congenital infection can occur regardless of the severity of maternal presentation; or perhaps might even be more common in children born to mothers with mild symptoms. A retrospective cohort study from a US hospital shows that severe or critical infection in the mother was not associated with vertical transmission of COVID-19.[80]

Transmission of protective antibodies from mother to fetus through the placenta could provide a tentative explanation for the lower proportion of congenital infections in newborns of mothers with severe or critical illness presentations found in this review; however there is no certainty regarding the role of antibodies transferred from the mother. Although some of these antibodies can neutralize viral particles, others facilitate their capture by cells with a high presence of Fc receptors, such as endothelial and syncytiotrophoblast cells, which would favor transplacental viral transmission.[70] Asymptomatic neonates or neonates presenting with mild symptoms born to women with COVID-19 confirmed either via nucleic acid tests or serology have presented with elevated levels of anti-SARSCoV-2-specific IgG but negative RT-PCR tests.[81]

\section{PERSPECTIVES}

More studies are required on intrauterine and intrapartum SARSCoV-2 transmission, and larger datasets are required before we can estimate the incidence of this phenomenon or perform causality analyses. Some registries have been working in this direction and various initiatives have emerged to catalogue vertical transmission. $[2,29,82]$

Current mathematical modeling suggests that combining drug-based therapies with vaccines could optimize treatment of diseases capable of both vertical and horizontal transmission.[83]

Although it is premature to propose drugs to prevent maternal-fetal transmission of SARS-CoV-2 and its effects on pregnancy, drugs that can influence levels of gene expression or enzymatic activity of ACE2 could be potential candidates. However, a better understanding is still needed of the ACE2-receptor contribution to facilitating viral entry into placental cells.[76,84] Passive immunization could be another option, due to its potential for minimizing effects of maternal viral infection in gestational products and in the fetal systemic inflammatory response.[85]

An ideal proposal would involve active immunization of pregnant women, but historically, pregnant and lactating women have not been included in such studies for safety reasons. It is possible that effective vaccination of the general population will prevent SARSCoV-2 infection in pregnant women through herd immunity. New proposals have been forwarded allowing for the use of vaccines in pregnant women during epidemics of emerging diseases, including WHO support for recommendations in 2019 by the Working Group on Research Ethics in Pregnancy, Epidemics and New Technologies. $[86,87]$ Nevertheless, before considering vaccination of pregnant women, the short- and long-term effects of COVID-19 on pregnancy, as well as on fetuses and newborns, should be investigated, as sufficient information is lacking. Related elements for further research are the type of vaccine to be used (platform, adjuvants, immunogenicity, toxicological analysis, etc.) and the likelihood of vaccine acceptance in this population group.

The main limitation of this review is the high level of uncertainty that persists regarding the timing of infection, which could not be determined in all cases. The strengths of the review lie in the novelty of the case-by-case analysis, the use of a new classification system, the decision to include only newborns of COVID-19-positive mothers who tested positive for the virus in the first 48 hours after birth or near this time limit, and the extensive review of articles published in both Spanish and English.

\section{CONCLUSIONS}

Congenital and intrapartum SARS-CoV-2 infection in the fetus/ newborn is possible, but rare. In the published literature, among newborns of COVID-19-positive mothers who tested positive in the first 48 hours of life, congenital and intrapartum infections account for just over a third of all infections. We recommend undertaking international collaborative studies at the population level using standardized instruments to determine the frequency of vertical transmission of SARS-CoV-2. - 1/ 


\section{REFERENCES}

1. Yang Z, Liu Y. Vertical transmission of Severe Acute Respiratory Syndrome Coronavirus 2: a systematic review. Am J Perinatol. 2020 Aug;37(10):1055-60.

2. Gale C, Knight M, Ladhani S, Draper ES, Sharkey D, Doherty $C$, et al. National active surveillance to understand and inform neonatal care in COVID-19. Arch Dis Child Fetal Neonatal Ed. 2020 Jul;105(4):346-7.

3. Schwartz DA, Thomas KM. Characterizing COVID-19 maternal-fetal transmission and placental infection using comprehensive molecular pathology. EBioMedicine. 2020 Oct;60:102983. DOI: https://doi.org/10.1016/j.ebiom.2020.102983.

4. Shah PS, Diambomba Y, Acharya G, Morris SK, Bitnun A. Classification system and case definition for SARS-CoV-2 infection in pregnant women, fetuses, and neonates. Acta Obstet Gynecol Scand. 2020 May;99(5):565-8.

5. Sola A, Maksimovic L, Montes Bueno MT, Rodríguez S, Cardetti M, Golombek SG, et al. Sociedad Iberoamericana de Neonatología y COVID-19 perinatal: Información y recomendaciones de SIBEN. [place unknown]: Ediciones SIBEN; 2020 Apr 17. 68 p. ISBN 978-1-7923-3225-8. Spanish.

6. Murad HM, Sultan S, Haffar S, Bazerbachi F. Methodological quality and synthesis of case series and case reports. BMJ. Evid Based Med. 2018 Apr;23(2):60-3.

7. Kotlyar A, Grechukhina O, Chen A, Popkhadze S, Grimshaw A, Tal O, et al. Vertical transmission of COVID-19: a systematic review and metaanalysis. Am J Obstet Gynecol. 2020 Jul 31. DOI: https://doi.org/10.1016/j.ajog.2020.07.049. Online ahead of print

8. Schwartz DA, Morotti D, Beigi B, Moshfegh F, Zafaranloo N, Patané L. Confirming vertical fetal infection with COVID-19: neonatal and pathology criteria for early onset and transplacental transmission of SARS-CoV-2 from infected pregnant mothers. Arch Pathol Lab Med. 2020 Dec 1;144(12):1451-6.

9. Sisman J, Jaleel MA, Moreno W, Rajaram V, Collins RR, Savani RC, et al. Intrauterine transmission of SARSCOV-2 infection in a preterm infant. Pediatr Inf Dis J. 2020;39:e265-7.

10. Wu Z, McGoogan JM. Characteristics of and important lessons from the coronavirus disease 2019 (COVID-19) outbreak in China: summary of a report of 72314 cases from the Chinese Center for Disease Control and Prevention. JAMA. 2020 Apr 7;323(13):1239-42. Online ahead of print 2020 Feb 24.

11. Wang C, Zhou YH, Yang HX, Poon LC. Intrauterine vertical transmission of SARS-CoV-2: what we know so far. Ultrasound Obstet Gynecol. 2020 Jun;55(6):724-5.

12. Schwartz DA Vertical transmission of Severe Acute Respiratory Syndrome Coronavirus 2 from the mother to the infant. JAMA Pediatr. 2020 Oct 1;174(10):1004-5.

13. Hecht JL, Quade B, Deshpande V, Mino-Kenudson $\mathrm{M}$, Ting DT, Desai N, et al. SARS-CoV-2 can infect the placenta and is not associated with specific placental histopathology: a series of 19 placentas from COVID-19-positive mothers. Mod Pathol. 2020 Nov;33(11):20922103. Online ahead of print 2020 Aug 2. DOI: https://doi.org/10.1038/s41379-020-0639-4.

14. Bahadur G, Homburg R, Yoong W, Singh C, Bhat $M$, Kotabagi $P$, et al. Adverse outcomes in SAR-CoV-2 (COVID-19) and SARS virus related pregnancies with probable vertical transmission. JBRA Assist Reprod. 2020 JulSep;24(3):351-7.

15. Diriba K, Awulachew E, Getu E. The effect of coronavirus infection (SARS-CoV-2, MERSCoV, and SARS-CoV) during pregnancy and the possibility of vertical maternal-fetal transmission: a systematic review and meta-anal- ysis. Eur J Med Res. 2020 Sep 4:25(1):39. DOI: https://doi.org/10.1186/s40001-020-00439-w.

16. Antoun L, Taweel NE, Ahmed I, Patni S, Honest H. Maternal COVID-19 infection, clinical characteristics, pregnancy, and neonatal outcome: a prospective cohort study. Eur J Obstet Gynecol Reprod Biol. 2020 Sep;252:559-62.

17. Akhtar H, Patel C, Abuelgasim E, Harky A. COVID-19 (SARS-CoV-2) infection in pregnancy: a systematic review. Gynecol Obstet Invest. 2020;85(4):295-306.

18. Kucirka LM, Lauer SA, Laeyendecker O, Boon D, Lessler J. Variation in false-negative rate of reverse transcriptase polymerase chain reaction-based SARS-CoV-2 tests by time since exposure. Ann Intern Med. 2020 Aug 18;173(4):262-7.

19. Penfield CA, Brubaker SG, Limaye MA, Lighter J, Ratner AJ, Thomas KM, et al. Detection of SARSCOV-2 in placental and fetal membrane samples. Am J Obstet Gynecol MFM. 2020 Aug;2(3):100133. DOI: 10.1016/j.ajogmf.2020.100133.

20. Wang S, Guo L, Chen L, Liu W, Cao Y, Zhang J, et al. A case report of neonatal COVID-19 infection in China. Clin Infect Dis. 2020 Jul 28;71(15):853-7.

21. Nie R, Wang S, Yang Q, Fan C, Liu Y, He W, et al. Clinical features and the maternal and neonatal outcomes of pregnant women with coronavirus disease 2019. J Infect. 2020 Jul;81(1):e40-e4

22. Khan S, Jun L, Nawsherwan, Siddique R, Li Y, Han $\mathrm{G}$, et al. Association of COVID-19 with pregnancy outcomes in health-care workers and general women. Clin Microbiol Infect. 2020 Jun;26(6):788-90.

23. Zhang Z-J, Yu X-J, Fu T, Liu Y, Jiang Y, Xiang Yang $B$, et al. Novel coronavirus infection in newborn babies aged $<28$ days in China. Eur Respir J. 2020 Jun 18:55(6):2000697. DOI: 10.1183/13993003.00697-2020.

24. Alzamora MC, Paredes T, Caceres D, Webb CM, Valdez LM, La Rosa M. Severe COVID-19 during pregnancy and possible vertical transmission. Am J Perinatol. 2020 Jun;37(8):861-5.

25. Govind A, Essien S, Karthikeyan A, Fakokunde A, Janga D, Yoong W. Re: Novel Coronavirus COVID-19 in late pregnancy: outcomes of fi rst nine cases in an inner city London hospital. Eur J Obstet Gynecol Reprod Biol. 2020 Aug;251:272-4.

26. Ferrazzi E, Frigerio L, Savasi V, Vergani P, Prefumo F, Barresi S, et al. Vaginal delivery in SARS-CoV-2 infected pregnant women in Northern Italy: a retrospective analysis. BJOG. 2020 Aug;127(9):1116-21.

27. Kalane S, Gokhale A, Patwardhan S. Early onset SARS-CoV-2 pneumonia in a preterm neonate Probably acquired through vertical transmission [Internet]. Durham: Research Square; 2020 Aug 14 [cited 2020 Sep 2]. DOI: https://doi.org/10.21203/ rs.3.rs-58363/v1.

28. Savasi VM, Parisi F, Patanè L, Ferrazzi E, Frigerio $\mathrm{L}$, Pellegrino A, et al. Clinical Findings and disease severity in hospitalized pregnant women with Coronavirus disease 2019 (COVID-19). Obstet Gynecol. 2020 Aug;136(2):252-8.

29. Knight M, Bunch K, Vousden N, Morris E, Simpson N, Gale C, et al. Characteristics and outcomes of pregnant women admitted to hospital with confirmed SARS-CoV-2 infection in UK: national population based cohort study. BMJ. 2020 Jun 8;369:m2107.

30. Sola A, Rodríguez S, Cardetti M, Dávila C. COVID-19 perinatal en América Latina. Rev Panam Salud Pública. 2020 Jul 31;44e: 47. DOI: https:// doi.org/10.26633/RPSP.2020.47. Spanish.

31. Vivanti AJ, Vauloup-Fellous C, Prevot $S$, Zupan V, Suffee C, Do Cao J, et al. Transplacental transmission of SARS-CoV-2 infection. Nat Commun. 2020 Jul 14;11(1):3572. DOI: 10.1038/s41467-020-17436-6.

32. Marzollo R, Aversa S, Prefumo F, Saccani B, Rodríguez Pérez C, Sartori E, et al. Possible Coro- navirus disease 2019 pandemic and pregnancy: vertical transmission is not excluded. Pediatr Inf Dis J. 2020 Sep;39(9):e261-2.

33. Facchetti F, Bugatti M, Drera E, Tripodo C, Sartori E, Cancila V, et al. SARS-CoV2 vertical transmission with adverse effects on the newborn revealed through integrated immunohistochemical, electron microscopy and molecular analyses of placenta. EBioMedicine. 2020 Sep;59:102951. DOI: https:// doi.org/10.1016/j.ebiom.2020.102951.

34. Kulkarni R, Rajput U, Dawre R, Valvi C, Nagpal R, Magdum N, et al. Early-onset symptomatic neonatal COVID-19 infection with high probability of vertical transmission. Infection 2020 Aug 2;1-5. DOI: https://doi.org/10.1007/s15010-020-01493-6. Online ahead of print.

35. Buonsenso D, Costa S, Sanguinetti M, Cattani P, Posteraro B, Marchetti S, et al. Neonatal late onset infection with severe acute respiratory syndrome coronavirus 2. Am J Perinatol. 2020 Jun;37(8):869-72.

36. Zamaniyan M, Ebadi A, Aghajanpoor S, Rahmani Z, Haghshenas M, Azizi S. Preterm delivery, maternal death, and vertical transmission in a pregnant woman with COVID-19 infection. Prenat Diagn. 2020 Apr 17:1-3. DOI: 10.1002/pd.5713. Online ahead of print.

37. Kirtsman M, Diambomba $\mathrm{Y}$, Poutanen SM, Malinowski AK, Vlachodimitropoulou E, Parks WT, et al. Probable congenital SARS-CoV-2 in a neonate born to a woman with active SARS-CoV-2 infection. CMAJ. 2020 Jun15;192(24):E647-50.

38. Patanè L, Morotti D, Giunta MR, Sigismondi C, Piccoli MG, Frigerio $L$, et al. Vertical transmission of COVID-19: SARS-CoV-2 RNA on the fetal side of the placenta in pregnancies with COVID-19 positive mothers and neonates at birth. Am J Obstet Gynecol MFM. 2020 Aug;2(3):100145. DOI: 10.1016/j.ajogmf.2020.100145.

39. Carosso A, Cosma S, Borella F, Marozio L, Coscia A, Ghisetti V, et al. Pre-labor anorectal swab for SARS-CoV-2 in COVID-19 pregnant patients: is it time to think about it? Eur J Obstet Gynecol Reprod Biol. 2020 Jun;249:98-9.

40. Dong L, Tian J, He S, Zhu C, Wang J, Liu C, et al. Possible vertical transmission of SARS-CoV-2 from an infected mother to her newborn. JAMA. 2020 May 12;323(18):1846-8.

41. Zeng $\mathrm{H}, \mathrm{Xu} \mathrm{C}$, Fan J, Tang $\mathrm{Y}$, Deng $\mathrm{Q}$, Zhang $W$, et al. Antibodies in infants born to mothers with COVID-19 pneumonia. JAMA. 2020 May 12;323(18):1848-9.

42. Gao J, Hu X, Sun X, Luo X, Chen L. Possible intrauterine SARS-CoV-2 infection: Positive nucleic acid testing results and consecutive positive SARSCoV-2-specific antibody levels within 50 days after birth. Int J Infect Dis. 2020 Oct;99:272-5.

43. Kimberlin DW, Stagno S. Can SARS-CoV-2 infection be acquired in utero? More definitive evidence is needed. JAMA. 2020 May 12;323(18):1788-9.

44. Simões E Silva AC, Leal CRV. Is SARS-CoV-2 vertically transmitted? Front Pediatr. 2020 May 15:8:276. DOI: 10.3389/fped 2020.00276.

45. Hinojosa-Velasco A, Bobadilla-Montes de Oca PV, García-Sosa LE, Mendoza-Durán JG, Pérez-Méndez MJ, Dávila-González E, et al. A case report of newborn infant with severe COVID-19 in Mexico: detection of SARS-CoV-2 in human breast milk and stool. Int J Infect Dis. 2020 Nov; 100:21-4.

46. Martínez-Pérez $O$, Vouga $M$, Cruz Melguizo $S$, Forcen Acebal L, Panchaud A, Muñoz-Chápuli M, et al. Association between mode of delivery among pregnant women with COVID-19 and maternal and neonatal outcomes in Spain. JAMA. $2020 \mathrm{Jul}$ 21;324(3):296-9.

47. Schwartz DA, Mohagheghi P, Beigi B, Zafaranloo N, Moshfegh F, Yazdani A. Spectrum of neonatal COVID-19 in Iran: 19 infants with 
SARS-CoV-2 perinatal infections with varying test results, clinical findings and outcomes. J Matern Fetal Neonatal Med. 2020 Aug 12;1-10. DOI: 10.1080/14767058.2020.1797672.

48. McDevitt KEM, Ganjoo N, Mlangeni D, Pathak S. Outcome of universal screening of neonates for COVID-19 from asymptomatic mothers. J Infect. 2020 Sep;81(3):452 -82.

49. Zeng L, Xia S, Yuan W, Yan K, Xiao F, Shao J, et al. Neonatal early-onset infection with SARSCoV-2 in 33 neonates born to mothers with COVID-19 in Wuhan, China. JAMA Pediatr. $2020 \mathrm{Jul}$ 1;174(7):722-5

50. Bordbar A, Kashaki M, Rezaei F, Jafari R. Vertical transmission of COVID-19 in a 1-day-old neonate. Travel Med Infect Dis. 2020 Sep 17;38:101879. DOI: 10.1016/j.tmaid.2020.101879.

51. Lorenz N, Treptow A, Schmidt S, Hofmann R, Raumer-Engler M, Heubner G, et al. Neonatal early-onset infection with SARS-CoV-2 in a newborn presenting with encephalitic symptoms. Pediatr Infect Dis J. 2020 Aug;39(8): e212.

52. Sinelli M, Paterlini G, Citterio M, Di Marco A, Fedeli T, Ventura ML. Early neonatal SARS-CoV-2 infection manifesting with hypoxemia requiring respiratory support. Pediatrics. 2020 Jul;146(1):e20201121.

53. Pierce-Williams RAM, Burd J, Felder $\mathrm{L}$, et al. Clinical course of severe and critical COVID-19 in hospitalized pregnancies: a US cohort study. Am J Obstet Gynecol. 2020;100134.

54. Gregorio-Hernández R, Escobar-Izquierdo $A B$, Cobas-Pazos J, Martínez-Gimeno A. Point-of-care lung ultrasound in three neonates with COVID-19. Eur J Pediatr. 2020 Aug;179(8):1279-85.

55. Khoury R, Bernstein PS, Debolt C, Stone J, Sutton DM, Simpson LL, et al. Characteristics and outcomes of 241 births to women with severe acute respiratory syndrome Coronavirus 2 (SARSCoV-2) infection at five New York City Medical Centers. Obstet Gynecol. 2020 Aug:136(2):273-82.

56. Chi H, Chiu NC, Tai YL, Chang HY, Lin CH, Sung $\mathrm{YH}$, et al. Clinical features of neonates born to mothers with coronavirus disease-2019: a systematic review of 105 neonates. J Microbiol Immunol Infect. 2020 Aug 14. DOI: 10.1016/j.jmii.2020.07.024 Online ahead of print.

57. Fornari F. Vertical transmission of Covid-19: a sys tematic review. J Pediatr Perinatol Child Health 2020 Apr 20;4(2):7-13.

58. Duran $\mathrm{P}$, Berman $\mathrm{S}$, Niermeyer $\mathrm{S}$, Jaenisch $\mathrm{T}$ Forster T, Gómez Ponce de León R, et al. COVID-19 and newborn health: systematic review. Rev Panam Salud Pública. 2020 Apr 27:44:e54. DOI: 10.26633/RPSP.2020.54.

59. Cabero-Pérez MJ, Gómez-Acebo I, DierssenSotos T, Llorca J. Infección por SARS-CoV-2 en el embarazo y posibilidad de transmisión al neonato: una revisión sistemática. Semergen. 2020 Aug;46 Suppl 1:40-7. Spanish.

60. Cavalcante de Melo G, Gomes Machado de Araújo KC. COVID-19 infection in pregnant women, preterm delivery, birth weight, and vertical transmission: a systematic review and meta-analysis. Cad Saúde Pública. 2020 Jul 17;36(7):e00087320. Online ahead of print.

61. Gajbhiye RK, Modi DN, Mahale SD. Pregnancy outcomes, newborn complications and maternal-fetal transmission of SARS-CoV-2 2 in women with COVID-19: a systematic review of 441 cases. medRxiv [Internet]. New York: Cold Spring Harbor Laboratory; 2020 May 5 [cited 2020 May 20]. Available at: https://doi.org/10.1101/2020.04.11.20062356

62. Gordon M, Kagalwala T, Rezk K, Rawlingson C, Idris Ahmed M, Guleri A. Rapid systematic review of neonatal COVID-19 including a case of presumed vertical transmission. BMJ Paediatr Open. 2020 May 25;4(1):e000718. DOI: 10.1136/ bmjpo-2020-000718.

https://doi.org/10.37757/MR2021.V23.N1.13
63. Pettirosso E, Giles M, Cole S, Rees M. COVID-19 and pregnancy: a review of clinical characteristics, obstetric outcomes and vertical transmission. Aust N Z J Obstet Gynaecol. 2020 Oct;60(5):640-59.

64. Lopes de Sousa AF, Félix de Carvalho HEF, Oliveira LB, Schneider G, Camargo ELS, Watanabe $E$, et al. Effects of COVID-19 infection during pregnancy and neonatal prognosis: what is the evidence? Int J Environ Res Public Health. 2020 Jun 11:17(11):4176.

65. Thamir Ahmed F, Sattar Jabbar S. Neonatal outcomes and vertical transmission in Covid-19 infected pregnant women; a systematic review. J Global Trends Pharm Sci. 2020 Jul;11(4):8589-95.

66. Dhir SK, Kumar J, Meena J, Kumar P. Clinical features and outcome of SARS-CoV-2 infection in neonates: a systematic review. J Trop Pediatr. 2020 Aug 28:fmaa059. DOI 10.1093/tropej/fmaa059. Online ahead of print.

67. Raschetti R, Vivanti A, Vauloup C, Loi B, Benachi A, De Luca D. Synthesis and systematic review of reported neonatal SARS-CoV-2 infections. Nat Commun. 2020 Oct 15;11(1):5164. DOI: https://doi .org/10.1038/s41467-020-18982.

68. AbdelMassih A, Fouda R, Essam R, Negm A, Khalil D, Habib D, et al. COVID-19 during pregnancy should we really worry from vertical transmission or rather from fetal hypoxia and placental insufficiency? A systematic review and meta-analysis [Internet]. Durham: Research Square; 2020 Sep [cited 2020 May 20]. Available at: https://doi .org/10.21203/rs.3.rs-71847/v1

69. Mahyuddin AP, Kanneganti A, Wong JJL, Dimri PS, Su LL, Biswas A, et al. Mechanisms and evidence of vertical transmission of infections in pregnancy including SARS-CoV-2. Prenat Diagn. 2020 Jun 12:10.1002/pd.5765. DOI: 10.1002/pd.5765. Online ahead of print.

70. Hosier H, Farhadian SF, Morotti RA, Deshmukh U, Lu-Culligan A, Campbell KH, et al. SARS-CoV-2 infection of the placenta. J Clin Invest. 2020 Sep 1;130(9):4947-53.

71. Algarroba GN, Rekawek P, Vahanian SA, Khullar P, Palaia T, Peltier MR, et al. Visualization of SARSCoV-2 virus invading the human placenta using electron microscopy. Am J Obstet Gynecol. 2020 Aug;223(2):275-8.

72. Komine-Aizawa S, Takada K, Hayakawa S. Placental barrier against COVID-19. Placenta [Internet]. 2020 Sep 15 [cited 2020 Sep 25];99:45-9. Available at: https://doi.org/10.1016/j.placenta.2020.07.022

73. Kreis NN, Ritter A, Louwen F, Yuan J. A message from the human placenta: structural and immunomodulatory defense against SARS-CoV-2. Cells. 2020 Jul 25;9(8):1777. DOI:10.3390/cells9081777.

74. Li M, Chen L, Zhang J, Xiong C, Li X. The SARSCoV-2 receptor ACE2 expression of maternalfetal interface and fetal organs by single-cell transcriptome study. PLoS One. 2020 Apr 16;15(4):e0230295. DOI: 10.1371/journal.pone .0230295 .

75. Pringle KG, Tadros MA, Callister RJ, Lumbers ER. The expression and localization of the human placental prorenin/renin-angiotensin system throughout pregnancy: roles in trophoblast invasion and angiogenesis? Placenta. 2011 Dec;32(12):95662.

76. Pique-Regi R, Romero R, Tarca AL, Luca F, Xu Y, Alazizi A, et al. Does the human placenta express the canonical cell entry mediators for SARS-CoV-2? Elife. 2020 Jul 14;9:e58716. DOI: https://doi.org/10.7554/eLife.58716.

77. Taglauer E, Benarroch Y, Rop K, Barnett E, Sabharwal V, Yarrington $C$, et al. Consistent localization of SARS-CoV-2 spike glycoprotein and ACE2 over TMPRSS2 predominance in placental villi of 15 COVID-19 positive maternal-fetal dyads. Placenta. 2020 Oct;100:69-74.
78. Wang W, Xu Y, Gao R, Lu R, Han K, Wu G, et al. Detection of SARSCoV-2 in different types of clinical specimens. JAMA. 2020 May 12;323(18):1843-4.

79. Hsu AL, Guan M, Johannesen E, Stephens AJ, Khaleel N, Kagan N, et al. Placental SARS-CoV-2 in a pregnant woman with mild COVID-19 disease. J Med Virol. 2020 Aug 4;101002/jmv.26386. DOI: 10.1002/jmv.26386. Online ahead of print.

80. Dumitriu D, Emeruwa UN, Hanft E, Liao GV, Ludwig E, Walzer L, et al. Outcomes of neonates born to mothers with severe acute respiratory syndrome Coronavirus 2 infection at a large medical center in New York City. JAMA Pediatr. 2020 Oct 12;e204298. DOI:10.1001/jamapedia trics.2020.4298. Online ahead of print.

81. Vendola N, Stampini V, Amadori R, Gerbino M, Curatolo A, Surico D. Vertical transmission of antibodies in infants born from mothers with positive serology to COVID-19 pneumonia. Eur J Obstet Gynecol Reprod Biol. 2020 Oct;253:331-2.

82. De Luca D, Rava L, Nadel S, Tissieres P, Gawronskiet O, Perkins E, et al. The EPICENTRE (ESPNIC Covid pEdiatric Neonatal Registry) initiative: background and protocol for the international SARS-CoV-2 infections registry. Eur J Pediatr. 2020 Aug:179(8):1271-8.

83. Bhattacharyya S, Ghosh S. Optimal control of verticalIy transmitted disease: an integrated approach. Comput Math Methods Med. 2010 Dec; 11(4):369-87.

84. Dambha-Miller $H$, Albasri A, Hodgson S, Wilcox $\mathrm{CR}$, Khan S, Islam N, et al. Currently prescribed drugs in the UK that could up or downregulate ACE2 in COVID-19 disease: a systematic review. BMJ Open. 2020 Sep 14;10(9): e040644.

85. Kaur SP, Gupta V. COVID-19 Vaccine: a comprehensive status report. Virus Res. 2020 Oct 15;288:198114. DOI: 10.1016/j.virusres.2020.198 114. Epub 2020 Aug 13

86. Krubiner $\mathrm{CB}$, Faden RR, Karron RA, Little $M O$, Lyerly $A D$, Abramson JS, et al. Pregnant women and vaccines against emerging epidemic threats: ethics guidance for preparedness, research, and response. Vaccine. 2019 May 3. DOI: https://doi.org.10.1016/j.vaccine.2019.01.011. [Epub ahead of print]

87. Heath PT, Le Doare K, Khalil A. Inclusion of pregnant women in COVID-19 vaccine development. Lancet Infect Dis. 2020 Sep;20(9):1007-8. Epub 2020 Aug 11

\section{THE AUTHORS}

Gerardo Rogelio Robaina-Castellanos (Corresponding author: grcastellanos.mtz@ infomed.sld.cu), neonatologist with a doctorate in medical sciences. Full professor and senior researcher, neonatology service, José Ramón López Tabrane Provincial Women's and Children's Hospital, Medical University of Matanzas, Matanzas, Cuba. https://orcid.org/0000-0003 $-0300-9871$

Solangel de la Caridad Riesgo-Rodríguez, physician with dual specialties in family medicine and pediatrics, and a master's degree in comprehensive child health. Head professor and adjunct researcher, Teaching and Research Department, Eliseo Noel Caamaño Pediatric Provincial Hospital, Medical University of Matanzas, Matanzas, Cuba. https://orcid.org/0000 $-0002-4634-6563$

Submitted: July 25, 2020

Approved for publication: December 31, 2020 Disclosures: None 